\title{
ALLOCATION OF EXPENDITURE OF POOR FAMILY AS A RECIPIENT OF PROGRAM KELUARGA HARAPAN (PKH)
}

\author{
Risda Rizkillah ${ }^{1 *}$, Megawati Simanjuntak ${ }^{2}$ \\ ${ }^{1,2}$ Lecturer in the Department of Family and Consumer Sciences, Faculty of \\ Human Ecology, Bogor Agricultural University, Bogor 16680 \\ *Corresponding author: mega.juntakipb@gmail.com
}

\begin{abstract}
The aim of this article is to examine the allocation of expenditure for low-income families after receiving the Program Keluarga Harapan (PKH) or Conditional Cash Transfer (CCT). Combination of cross-sectional and retrospective designs were applied in this research. Data collection locations were carried out in eight villages in Dramaga District, Bogor Regency. The research sample was determined randomly (probability sampling) used a systematic method and obtained a study sample of 150 CCT recipient families. Data was processing used descriptive statistics. The CCT funding eligible for the family who has school-age children, toddlers, nursing mother, and pregnant woman. The CCT funds are spent by families with an average range of two weeks. The beneficiary of PKH significantly improving the quality of education and health, increasing the amount of family savings, and family income. The allocation of CCT funds more than half is used for human investment. However, in the allocation of CCT funds, there are still families who use PKH funds for non-educational activities such as food/household needs, pay-off debt, saving, electricity payment, and business capital.
\end{abstract}

Keywords: Cash Conditional Transfer, expenditure allocation, PKH Recipient, PKH Benefits

\begin{abstract}
Abstrak
Penelitian ini bertujuan mengkaji perubahan alokasi pengeluaran keluarga miskin pasca mendapat Program Keluarga Harapan (PKH). Studi ini menerapkan kombinasi disain cross-sectional dan retrospektif. Lokasi pengambilan data dilakukan di delapan desa yang terdapat di Kecamatan Dramaga, Kabupaten Bogor. Sampel penelitian ditentukan secara acak (probability sampling) dengan menggunakan metode sistematik dan didapatkan sample penelitian sebanyak 150 keluarga penerima PKH. Pengolahan data menggunakan statistika deskriptif. Hasil penelitian menunjukkan alasan keluarga mendapat dana PKH karena adanya anak usia sekolah, balita, ibu menyusui, dan ibu hamil. Dana PKH dihabiskan oleh keluarga dengan kisaran rata-rata waktu dua minggu. Manfaat yang sangat dirasakan oleh penerima $\mathrm{PKH}$ adalah peningkatan kualitas pendidikan dan kesehatan, meningkatnya jumlah tabungan keluarga, dan pendapatan total keluarga. Alokasi dana PKH lebih dari separuhnya digunakan untuk investasi manusia dan sepertinganya untuk kegiatan konsumtif. Namun dalam pengalokasian dana $\mathrm{PKH}$ masih ada keluarga yang menggunakan dana $\mathrm{PKH}$
\end{abstract}


untuk kegiatan non-pendidikan seperti kebutuhan makanan/kebutuhan dapur, membayar utang, tabungan, membayar listrik, dan modal usaha.

Kata kunci: Alokasi pengeluaran, Manfaat PKH, Program Keluarga Harapan, Penerimaan PKH,

\section{Introduction}

Family welfare is the primary goal of Indonesian families. In order to manifest of family welfare, the government must beware of poverty which cannot be separated from the problem of fulfilling the necessities of life. Poverty outcomes are the low quality of education and health which affect certain groups and caused the productivity imbalanced hence threatened family's future. The characteristics of low-income households according to Miftahuddin (2011) generally have these characteristics: low education, working in the agricultural sector, women, many family member, laborers and having 35 hours/week working hours.

Multifarious efforts have been made by the Indonesian government to provide opportunities for the low-income family to improve their welfare, for instance Jaring Pengaman Sosial (JPS), Subsidi Langsung Tunai (SLT), Beras Miskin (Raskin), Asuransi Kesehatan untuk Masyarakat Miskin (Askeskin), Bantuan Operasional Sekolah (BOS), Program Nasional Pemberdayaan Masyarakat Mandiri (PNPM), and the latest launched program was the Program Keluarga Harapan (PKH). Poverty alleviation programs before $\mathrm{PKH}$ were declared failed by certain parties for they determination was only to channel social assistance to the poor and lack of understanding by various parties about the causes of poverty itself thus development programs were not based on poverty issues, the causes vary locally. Such force will be challenging to solve the existing poverty issues since the nature of aid was not meant for empowerment, it can lead to dependence. These assistance programs oriented to government generosity could worsen the morals and behavior of the unfortunate families. On the other hand, these social assistance programs could also cause corruption in the midst of distribution.

Program Keluarga Harapan $(\mathrm{PKH})$ is a conditional cash transfer program that beneficiaries of this program will receive cash assistance as long as they fulfill their mandatories. PKH is a social protection program through the provision of cash assistance to impoverished families, which have pregnant, postpartum, or breastfeeding mother; or preschool toddler; or have children who are still in the primary or middle school ; children ages 15-18 years who are still in primary education or have not completed yet. The PKH family ought to send their children to a certain level of attendance in school, check their health and/or pay attention to the adequacy of nutrition and healthy lifestyle for children and pregnant women (TNP2K, 2015). Similar programs in other countries known as Conditional Cash Transfers (CCT) or limited cash assistance aim to break the intergenerational poverty and foster human resources (Stampini and Tornarolli, 2012).

The evaluation of the impact of CCT PROGRESA in Mexico, PETI in Brazil and RPS pilots in Nicaragua showed that CCT can provide adequate 
incentives for HR investment in low-income families. In the education sector, the program shows a positive effect on school enrollment rates for boys and girls. Besides, the nutritional status and health of children also increased as a result of the CCT Program (Gertler 2000; Behrman and Hoddinott 2000).

A study conducted by Puspitawati et al. (2006) on the impact of SLT on families' welfare in Bogor shows that SLT funds could reduced family stress; could used for food, housing, education, health, paying debts, capital, giving relatives/children, zakat, etc ; and women's burden is reduced, also could intensify interaction between families. However, Kholif et al. (2014) show that PKH implementation has not been successful yet. Not all the policies are carried out accordingly, and the PKH objectives have not yet obtained maximum results. Poverty, malnutrition, maternal mortality rate and unqualified community support still exist. Based on the background's explanation, it is the basis for the need for research to assess the expenditure allocation of low-income families receiving the Program Keluarga Harapan (PKH).

\section{Method}

Combination of cross-sectional and retrospective designs were applied in this study. Data collection locations were carried out in eight villages in Dramaga District, Bogor Regency. Bogor Regency was deliberately chosen based on consideration of PKH pilot area for the West Java region and included in the five districts with the most $\mathrm{PKH}$ recipient households. Subsequently, Dramaga Subdistrict was chosen for the availability of a PKH sampling frame so that random sampling was possible.

The population of this study was all $\mathrm{PKH}$ recipient families in Dramaga District who accepted PKH. The samples were mothers of PKH recipient families which were determined randomly (probability sampling) using a systematic method and obtained a study sample of $150 \mathrm{PKH}$ recipient families. Primary data collected including demographic characteristics (family size, family structure, and parents' age), and socio-economic (parental education level, parental work, expenses, assets), total family income, reasons for obtaining $\mathrm{PKH}$ funds, $\mathrm{PKH}$ large funds, $\mathrm{PKH}$ funds benefits, $\mathrm{PKH}$ funds savings and $\mathrm{PKH}$ funds allocation. Secondary data collected included the implementation of the $\mathrm{PKH}$ program through a review of PKH guidelines including $\mathrm{PKH}$ recipient data in Dramaga District and its distribution system, as well as village and sub-district profiles obtained from Central Bureau Statistics (BPS) Bogor, village offices, local subdistrict offices, local post offices, and PKH assistants of Dramaga District. Secondary data is collected by a person or organization other than data users. Data processing used descriptive and inferencing statistics.

\section{Findings}

\section{Family Characteristic}

The National Population and Family Planning Agency (BKKBN) divides large families into categories namely small families ( $\leq 4$ people), medium families 
(5-6 people), and large families (> 6 people). Study found more than half of the families $(58.0 \%)$ belong to the medium category. The average number of family members in this study were six people. Most of the samples $(84 \%)$ belong to the nuclear family category, which consists of father, mother, and child while the rest are in the broad family category.

Based on the results of different tests, there was a significant differences ( $\alpha$ $=0,000$ ) between the age of the father and the age of the mother. The average age of father was 44.59 years and 38.41 years for mothers. Majority of fathers $(90.8 \%)$ and all mothers (100\%) fall under the productive age category (15 to 64 years). The average education of fathers ( 4.83 years) and mothers ( 3.76 years) are still deficient. More than half $(59.1 \%)$ of mothers and more than a third of fathers $(38.3 \%)$ did not graduate from primary school. Statistically, different test results found a significant differences $(\alpha=0,000)$ between father and mother education, which is father's education higher than the mother's education.

The results showed that the pre-PKH fathers who had the primary job were 96.0 percent, which decreased to 94.2 percent when the family received $\mathrm{PKH}$ funds. However, for additional work, there was an increase from 10.8 percent to pre-PKH to 12.8 percent when receiving PKH funds. Furthermore, there was 4.3 percent of fathers who did not work pre-PKH, even when PKH the percentage increased to 6.1. The main types of main work occupied by fathers are laborers, both non-farm and farm laborers who are sporadic. The results showed that in prePKH conditions, the mothers who had the primary job were 45.6 percent who had increased to 47.0 percent when the family received PKH funds. Likewise, for additional jobs there was an increase from 2.7 percent pre-PKH to 4.7 percent when families received PKH funds. The main types of mothers' work are laborers, including sporadic work, whether they are domestic servants or farm laborers.

\section{The motive of Getting Program Keluarga Harapan (PKH)}

The reason families get PKH funding is not only because of the presence of school-age children also the presence of toddlers, nursing mothers, pregnant women or middle-school age children. Those are the basis of amount diversification of the beneficiary of PKH funds. Based on the research data, it was obtained a mapping of the reasons for families receiving $\mathrm{PKH}$ funding, namely one reason (there are children in primary or middle school) 56 percent, a combination of two reasons as much as 30.7 percent and a combination of three reasons as much as 13.4 percent.

Table 1 Sample distribution based on family's motive of getting PKH (answers can be more than one)

\begin{tabular}{|c|c|c|c|c|c|c|}
\hline \multicolumn{5}{|c|}{ The motive of getting PKH $(n=150)$} & \multirow{2}{*}{$\mathrm{n}$} & \multirow{2}{*}{$\%$} \\
\hline $\mathrm{A}^{*}$ & $\mathrm{~B}^{*}$ & $\mathrm{C}^{*}$ & D* & $\mathrm{E}^{*}$ & & \\
\hline \multirow{4}{*}{$\mathrm{V}$} & & & $\mathrm{V}$ & & 84 & 56,0 \\
\hline & & & $\mathrm{V}$ & & 33 & 22,0 \\
\hline & V & & V & & 4 & 2,7 \\
\hline & & & $\mathrm{V}$ & $\mathrm{V}$ & 9 & 6,0 \\
\hline $\mathrm{V}$ & $\mathrm{V}$ & & $\mathrm{V}$ & & 8 & 5,3 \\
\hline
\end{tabular}


Rizkillah \& Simanjuntak / Journal of Family Sciences , 2018, Vol. 03, No. 01

\begin{tabular}{|c|c|c|c|c|c|c|}
\hline \multicolumn{5}{|c|}{ The motive of getting PKH $(n=150)$} & \multirow{2}{*}{$\mathrm{n}$} & \multirow{2}{*}{$\%$} \\
\hline $\mathrm{A}^{*}$ & $\mathrm{~B}^{*}$ & $\mathrm{C}^{*}$ & D* & $\mathrm{E}^{*}$ & & \\
\hline $\mathrm{V}$ & & $\mathrm{V}$ & $\mathrm{V}$ & & 1 & 0,7 \\
\hline $\mathrm{V}$ & & & $\mathrm{V}$ & $\mathrm{V}$ & 10 & 6,7 \\
\hline $\mathrm{V}$ & & $\mathrm{V}$ & $\mathrm{V}$ & $\mathrm{V}$ & 1 & 0,7 \\
\hline
\end{tabular}

Notes :* A. Toddlers; B. Breastfeeding Mother; C. Pregnant women; D. Pimary school children and E. Middle school children

The amount of PKH funds received by families that have school-age children will vary depending on the child's education level and the number of children attending school at that level. The results also showed that the number of children receiving $\mathrm{PKH}$ funds in the family ranged from one to three people. The percentage of families with one child as the recipient of PKH funds was 48 percent, two children 40.7 percent and the rest with three children, namely 11.3 percent.

\section{Total Funds of Program Keluarga Harapan (PKH)}

Six times of the disbursement of PKH funds, the average fund received was IDR 597,247.7. The highest average amount of PKH funds is in the second stage (IDR 1,094,406.7), while the lowest average disbursement is in the sixth stage (IDR 491,086.7). The highest amount of PKH funds received by the sample family is IDR 1,867,000, namely in the second stage disbursement. In total, out of the six PKH fund withdrawals, funds that have been absorbed by $\mathrm{PKH}$ recipient families, on average, are IDR 3,583,480 with the lowest value being IDR $1,200,000$ and the highest value is IDR 6,020,000.

The average length of time for a sample of $\mathrm{PKH}$ recipients to spend $\mathrm{PKH}$ funds received is around two weeks. Even based on the statement of the sample, the funds obtained can be exhausted within one day, which is usually used to pay off debts. Of the six PKH fund withdrawals that have been made, based on the sample recognition, there is a tendency for the percentage to increase from the example stating that there is a portion left to the husband. The percentage of samples that gave a portion of PKH funds to husbands increased from 18 percent in the first stage to 51.3 percent in the sixth stage with an average of all stages of 43.7 percent. The percentage of the portion of funds handed over to husbands ranged from 2.6 to 4.7 percent, with an average of 4.0 percent. In general, the sample stated that $\mathrm{PKH}$ funds given to husbands are to buy cigarettes with an average portion of the funds given is IDR 22368.33 .

Table 2 The average and percentage of PKH funds that are handed over to the husband

\begin{tabular}{cccc}
\hline Stage & $\begin{array}{c}\text { The percentage that gives part of } \\
\text { the funds to the husband (\%) }\end{array}$ & $\begin{array}{c}\text { Percentage of } \\
\text { funds received by a } \\
\text { husband (\%) }\end{array}$ & $\begin{array}{c}\text { The average of PKH } \\
\text { funds that are handed over } \\
\text { to the husband } \\
\text { (IDR) }\end{array}$ \\
\hline I & 18,0 & 4,2 & 20660,0 \\
II & 32,7 & 2,6 & 28143,3 \\
\hline III & 42,7 & 4,7 & 23960,0 \\
IV & 56,0 & 4,4 & 21793,3 \\
V & 61,3 & 4,1 & 20326,7 \\
\hline
\end{tabular}




\begin{tabular}{cccc}
\hline Stage & $\begin{array}{c}\text { The percentage that gives part of } \\
\text { the funds to the husband }(\%)\end{array}$ & $\begin{array}{c}\text { Percentage of } \\
\text { funds received by a } \\
\text { husband }(\%)\end{array}$ & $\begin{array}{c}\text { The average of PKH } \\
\text { funds that are handed over } \\
\text { to the husband } \\
\text { VI }\end{array}$ \\
\cline { 2 - 3 } Mean & 51,3 & 3,9 & $\begin{array}{c}\text { (IDR) } \\
19326,7\end{array}$ \\
\hline
\end{tabular}

\section{Savings from Program Keluarga Harapan (PKH) Funds}

Based on the results of the study, less than one-third of the samples set aside a portion of the funds received for saving. The average amount saved is IDR 28,721.30. Disbursement with the smallest average is IDR 19,395.5 (stage VI) to IDR 57,499.6 (stage II). The amount saved ranged from zero to IDR 500,000. When compared with the average number of PKH funds received by the sample families, the percentage saved was between 3.9 to 5.3 percent or an overall average of 4.7 percent. Savings are managed by the group leader, where savings can be made at any time.

As many as 42.7 percents of the samples stated that they regularly saved on the PKH group and with the same percentage stated that they sometimes saved. There was 9.3 percent who stated that they had never saved because the money had already been allocated. More or less, there are 128 families who saved, almost all respondents $(97.7 \%)$ immediately deposited their savings to the group leader when they received PKH funds, while the rest deposited a portion of the funds received one or two days later or two or three weeks after that. The average savings amount is IDR 81,366.67 with the highest percentage $(49.2 \%)$ in the range between IDR 50,000 and IDR 100,000 (Table 3).

Table 3 Distribution of saving activities in the PKH group

\begin{tabular}{|c|c|c|c|}
\hline No & Saving Activities at PKH Groups & $\mathrm{n}$ & $\%$ \\
\hline \multicolumn{4}{|c|}{ Mother Involvement (n=150) } \\
\hline 1. & Seldom & 64 & 42,7 \\
\hline 2. & Always & 64 & 42,7 \\
\hline 3. & Never & 14 & 9,3 \\
\hline 4. & No Savings activities & 8 & 5,3 \\
\hline \multicolumn{4}{|c|}{ Deposit Time (n=128) } \\
\hline 1. & Directly, after receiving PKH funds & 125 & 97,7 \\
\hline 2. & Indirect & 3 & 2,3 \\
\hline \multicolumn{4}{|c|}{ Amount of PKH savings (n=128) } \\
\hline 1. & $<$ IDR 50000 & 30 & 23,4 \\
\hline 2. & IDR 50 000- IDR 100000 & 63 & 49,2 \\
\hline & > IDR 100000 & 35 & 27,3 \\
\hline \multicolumn{2}{|c|}{ Mean \pm SD (IDR) } & \multicolumn{2}{|c|}{$81366,67 \pm 75471,44$} \\
\hline \multicolumn{2}{|c|}{ Min-Max } & \multicolumn{2}{|c|}{$0-410000$} \\
\hline
\end{tabular}




\section{Benefits of Program Keluarga Harapan (PKH)}

Most of the samples (98.0\%) stated that they felt the benefits of $\mathrm{PKH}$. Around 75 percent of the samples stated that PKH will reduce poverty in Indonesia. As many as 15 questions used to interview the family related to family conditions when obtaining PKH funds, several items experienced an increase, namely the quality of children's education (83.3\%), the number of family savings (76.7\%), and total family income $(76.0 \%)$. Meanwhile, more than 75 percent of the samples stated the amount of control of assets (selling, pawning) (86.7\%), capital for business $(84.7 \%)$, ability to provide loans to relatives $(75.3 \%)$, quality of work $(90.7 \%)$, family $(81.3 \%)$, social relations with neighbors $(92.7 \%)$, conflicts / quarrel in the family $(82.7 \%)$, and domestic violence $(96.0 \%)$ did not change when the family received PKH funds. Family conflicts/arguments also decreased when families received PKH funds (16.7\%) (Table 4).

Table 4 Distribution of benefits felt by the family when getting PKH funds compared to pre-PKH

\begin{tabular}{llccc}
\hline \multirow{2}{*}{ No } & Family Condition & \multicolumn{3}{c}{ The family condition during PKH } \\
\cline { 3 - 5 } & & Decreased & Constant & Increased \\
\cline { 3 - 5 } & & 2,7 & 21,3 & 76,0 \\
1. & Total family income & 0,7 & 50,0 & 49,3 \\
2. & Family food expenditure & 1,3 & 42,0 & 56,7 \\
3. & Family non-food expenditure & 2,7 & 86,7 & 10,7 \\
4. & Amount of control of assets (selling, pawning) & 1,3 & 84,7 & 14,0 \\
5. & Capital for business & 1,3 & 44,7 & 54,0 \\
6. & Amount of family food & 1,3 & 22,0 & 76,7 \\
7. & Amount of family saving & 4,0 & 75,3 & 20,7 \\
8. & Ability to provide loans to relatives & 2,7 & 14,0 & 83,3 \\
9. & Quality of children's education & 5,3 & 55,3 & 39,3 \\
10. & Quality of family health & 2,7 & 90,7 & 6,7 \\
11. & Quality of work & 3,3 & 81,3 & 15,3 \\
12. & Quality of family relationship & 1,3 & 92,7 & 6,0 \\
13. & Social relations with neighbors & 16,7 & 82,7 & 0,7 \\
14. & Conflict/quarrel in the family & 3,3 & 96,0 & 0,7 \\
15. & Domestic violence & & & \\
\hline
\end{tabular}

\section{Allocation of Expenditure of Program Keluarga Harapan (PKH)}

Data on the allocation of expenditure for PKH funds taken in this study is for all the children and family members because it is difficult to record expenditure allocations for children as a sample. The amount of expenditure with the allocation of funds received at the sixth stage with total expenditure is not the same because of the limitations of the example of remembering.

The allocation of PKH funds to the last disbursement received by sample families is presented in Table 5. The allocation of $\mathrm{PKH}$ funds for children's education is 55.3 percent allocated to needs such as school bags and shoes $(17.1 \%)$ and red and white, scouts, and sports uniform costs (16.7\%). PKH funds are allocated for non-education such as food needs/kitchen needs (15.5\%), paying debts $(8.5 \%)$, savings (4.0\%), paying electricity (3.5\%), and venture capital 
(3.5\%). The results showed that the allocation of PKH funds for health purposes was minimal, only 0.5 percent.

After the mother has received the funds, some of the funds are saved either directly after the funds are received or a few days after that. One-tenth part of the funds received is left to the husband, which is generally used for cigarette consumption. The part of PKH funds for education is used by all children who are still in school in the sample family, so not only for PKH recipient children. If the PKH fund allocation is approached by grouping for human investment, productive and consumptive activities, it is seen that the most significant percentage still used for human investment is around 55.3 percent. Meanwhile, for productive activities 3.5 percent, while for consumptive activities by 33.9 percent, the rest is for deductions and savings.

Table 5 Allocation of expenditure on PKH funds to the last disbursement received by the samples

\begin{tabular}{|c|c|c|c|c|}
\hline Type of Expenditure & $\begin{array}{l}\text { Average } \\
\text { (IDR) }\end{array}$ & $\begin{array}{l}\text { Standard } \\
\text { Deviation }\end{array}$ & $\begin{array}{c}\% \text { towards } \\
\text { PKH Total } \\
\text { Funds }\end{array}$ & $\begin{array}{l}\text { Amount } \\
(\mathrm{n})\end{array}$ \\
\hline \multicolumn{5}{|l|}{ Education } \\
\hline - Transport fee & 606,67 & 3249,98 & 0,2 & 8 \\
\hline - Pocket money & 15100,00 & 36757,82 & 3,6 & 50 \\
\hline $\begin{array}{l}\text { - BP3 and Development } \\
\text { Costs }\end{array}$ & 6006.67 & 49437.69 & 1,4 & 10 \\
\hline - School Fees (SPP) & 8073,33 & 31865,72 & 1,9 & 15 \\
\hline - Additional learning costs & 4220,00 & 35106,52 & 1,0 & 6 \\
\hline - Books and stationery & 29386,66 & 30714,43 & 7,1 & 150 \\
\hline - Textbooks & 5100,00 & 17105,67 & 1,2 & 23 \\
\hline - Bag and shoes & 71046,67 & 61403,86 & 17,1 & 116 \\
\hline $\begin{array}{l}\text { Extra Curricular and } \\
\text { School Committees }\end{array}$ & 1713,33 & - & 0,4 & 6 \\
\hline - Students worksheets & 4233,33 & 163,30 & 1,0 & 34 \\
\hline - Uniform & 69553,34 & 61958,41 & 16,7 & 142 \\
\hline - School Events & 15230,00 & 16804,34 & 3,7 & 23 \\
\hline TOTAL OF EDUCATION & 230270,00 & 150308,88 & 55,3 & \\
\hline \multicolumn{5}{|l|}{ Non-Education } \\
\hline - Food/Kitchen need & 65070,00 & 78383,37 & 15,5 & 150 \\
\hline - Pay debts & 35228,00 & 61194,83 & 8,5 & 66 \\
\hline - Pay electricity & 14724,67 & 21172,34 & 3,5 & 64 \\
\hline $\begin{array}{l}\text { - Savings (PKH and Non- } \\
\text { PKH) }\end{array}$ & 16666,67 & 21772,67 & 4,0 & 76 \\
\hline - Venture capital & 14413,33 & 57654,51 & 3,5 & 13 \\
\hline $\begin{array}{l}\text { - Chair of the group and } \\
\text { RT }\end{array}$ & 13973,34 & 37887,67 & 3,4 & 85 \\
\hline $\begin{array}{l}\text { - PKH Transportation (to } \\
\text { post office) }\end{array}$ & 7246,67 & 36103,49 & 1,7 & 26 \\
\hline - Clothes & 1246,67 & 9208,21 & 0,3 & 6 \\
\hline - Given to husband & 350,00 & 3051,98 & 0,1 & 2 \\
\hline - Donations / Shodaqoh / & 8053,33 & 61316,67 & 2,0 & 11 \\
\hline
\end{tabular}




\begin{tabular}{|c|c|c|c|c|}
\hline Type of Expenditure & $\begin{array}{l}\text { Average } \\
\text { (IDR) }\end{array}$ & $\begin{array}{l}\text { Standard } \\
\text { Deviation }\end{array}$ & $\begin{array}{l}\% \text { towards } \\
\text { PKH Total } \\
\text { Funds }\end{array}$ & $\begin{array}{l}\text { Amount } \\
(\mathrm{n})\end{array}$ \\
\hline $\begin{array}{l}\text { Celebration / Arisan / } \\
\text { given to parents }\end{array}$ & & & & \\
\hline $\begin{array}{l}\text { - Repairing the House / } \\
\text { Furniture }\end{array}$ & 4933,33 & 43706,12 & 1,2 & 4 \\
\hline - Heath needs & 2266,67 & 16174,25 & 0,5 & 4 \\
\hline - Buy Gold & 2366,67 & 21672,49 & 0,6 & 2 \\
\hline $\begin{array}{l}\text { TOTAL OF NON- } \\
\text { EDUCATION }\end{array}$ & 186539,35 & 145582,07 & 44,8 & \\
\hline TOTAL OF PKH FUNDS & 416809,35 & 198749,56 & 100 & \\
\hline
\end{tabular}

\section{Discussion}

Program Keluarga Harapan (PKH) plays a vital role in efforts to reduce the poverty and improve the quality of human Resources in Indonesia. An essential aspect of the PKH program is women in this case mothers as recipients of PKH funds. The reason most families accept PKH is because they have primary schoolage children or middle-school children. The short-term benefits of PKH provide an income effect to low-income households that can be realized by increasing family income compared to before families received PKH. The high benefits felt by the sample family when getting PKH funds to include being able to buy children's school equipment, be able to pay for children's tuitition and provide happiness and motivation for their life. However, the benefits of PKH funds to become venture capital, help finance other relatives, reduce family conflict and pay-off debts did not make a significant contribution. In line with Irmayani and Nainggolan (2015) and Rozi (2011) who stated that PKH recipients felt that they obtained new benefits in the form of new insights and knowledge in the fields of formal education and health that were previously unknown, convenient for education, children's health, feeling healthier with the increasing frequency of visits to health care facilities, and being able to develop broader social relations. Increased family acceptance has implications for decreasing economic pressure and maternal stress, and in the end, the mother will feel more prosperous or satisfied with her life. For this reason, this program can be referred to as an incentive-based welfare program. The PKH program is felt to help poor people overcome poverty by reducing the main obstacles faced by the poor.

The length of time for the PKH sample recipient's family to spend the PKH funds received is around two weeks. Even though based on the statement of the sample of the funds obtained can be exhausted within one day, which is usually used to pay off debts. From the PKH funds received there were parts given to husbands by wives who were generally used by husbands to buy cigarettes whereas PKH funds are should have only used to improve the quality of education and health. This shows that there are still participants who use PKH funds in an inappropriate way. Hutagalung and Arif (2009) stated that PKH had increased the role of women (mothers) as recipients of assistance. However, in the implementation of the husband's intervention is still high in the household decision making. 
The PKH General Guidelines issued by the UPPKH (Unit Pelaksana Program Keluarga Harapan) Center in 2007 stated that there were no restrictions on the allocation of PKH funds obtained but as an effort to maximize the use of funds for family needs. Participants can use PKH assistance for any needs as long as they fulfill education and health requirements. The program will not monitor the use of aid money. One of the PKH funds allocations is for savings, almost half of the samples are saving regularly to the group leader. Almost all samples, saving directly after getting funds.

The allocation of PKH funds more than half is allocated for education. This is in line with the research of Utomo, Hakim, \& Ribawanto (2014) which states that PKH recipients are willing to carry out and fulfill their commitments due to fear of sanctions given. The high cost of education means that the access of the poor to education will be limited. Although the government officially abolished Education Support Donations, the fact is that people still have to pay for various items such as books, stationery, uniforms, shoes, transportation costs to schools and daily expenses. These costs become obstacles for the poor when sending their children to school. Few allocations of PKH funds are allocated to access health needs or facilities. This result is in line with Suntiana et al. (2015) which stated that money was not used to access health because health service facilities were provided free of charge so that aid money could be used for other needs such as improving nutrition services from food consumed or drinks.

The allocation of $\mathrm{PKH}$ funds is mostly used for human investment activities, one third for consumer activities, and the remainder for productive activities and savings. This is in line with the results of the research of Soares and Silva (2010), the implementation of Bolsa Familia or cash conditional transfer shows that there has not been a significant effect of an increase in public consumption. The program only affects the expenditure on children's education. The attendance rate of school children is increased with the decline in the previous school attendance rate of 3.6 percent to 1.6 percent. Thus, the example is still allocating PKH funds received in activities that are in line with PKH's mission to improve the quality of their children's education.

\section{Conclusion and Recommendation}

\section{Conclusion}

The number of PKH recipient family members ranges from 5 to 6 people with a family structure that is a nuclear family, and the age of the father and mother ranges from 30 to 49 years. The education level of fathers and mothers is only up to elementary school with a father's profession as a laborer, while most mothers do not work.

The reason families get PKH funding is because of school-age children, toddlers, nursing mothers, and pregnant women. PKH funds are spent by families with an average range of two weeks, and some even run out within one day. The benefits that PKH recipients significantly felt were improving the quality of education and health, increasing the number of family savings, and total family income. The allocation of PKH funds more than half is used for human 
investment and consumptive activities. However, in the allocation of PKH funds, there are still families who use PKH funds for PKH funds that are allocated for non-educational activities such as food needs/kitchen needs, buying cigarettes, paying debts, saving, paying for electricity, and working capital.

\section{Recommendation}

Although this research study was not a program evaluation, when exploring $\mathrm{PKH}$ implementation in Dramaga Subdistrict, there were still weaknesses in achieving PKH's mission, namely increasing human investment through improving the quality of children. For this reason, the government needs to make improvements from the central level to the recipients so that this program does not fail. Program evaluation can be carried out comprehensively for the three aspects that concern PKH funds, namely the health and education sectors because the funds received by the family can be in the form of a mixture of the three aspects.

\section{References}

Behrman, J, Hoddinott, J. (2000). An evaluation of the impact of Progress on preschool child height. International Food Policy Research Institute, Washington, DC. http://ideas.repec.org/p/fpr/fcnddp/104.html.http:// www.ifpri.org/themes/progresa/pdf/Gertler_health.pdf $\quad\left[\begin{array}{ll}18 & \text { September }\end{array}\right.$ 2009].

Gertler, PJ. (2000). Final report: The impact of Progress on health. International Food Policy Research Institute, Washington, D.C. http://www.ifpri.org/ themes/progresa/pdf/Gertler_health.pdf [18.

Hutagalung, SA., Sirojuddin, A., \& Widjajanti I.S. (2009). Problems and Challenges for the Indonesian Conditional Cash Transfer ProgrammeProgram Keluarga Harapan (PKH).' SMERU Working Paper Issue 4 Jakarta: The SMERU Research

Irmayani, \& Nainggolan, T. (2015). Perilaku Coping Penerima Program Keluarga Harapan (PKH) Menjelang Exit Program Di Jakarta Utara. Sosio Konsepsia, 4(3), 177-193.

Kholif, KI., Noor, I., \& Siswidiyanto. (2014). Implementasi Program Keluarga Harapan (PKH) dalam Menanggulangi Kemiskinan di Kecamatan Dawarblandong Kabupaten Mojokerto. Jurnal Administrasi Publik, 2(4), 709-714.

Miftahuddin. (2011). Analisa Karakteristik Rumah Tangga Miskin dengan Metode Regresi Logistik Terbaik. Jurnal Matematika, Statistika, \& Komputasi, 7(2), 79-91.

Rozi, U. (2011). Implementasi Program Keluarga Harapan di Kabupaten Tanah Laut. Cocus,1(2), 49-80.

Puspitawati H, Herawati T, Sarma M. (2008). Dampak Subsidi Langsung Tunai (SLT)- BBM pada Kesejahteraan Keluarga Miskin Di Bogor, Jawa Barat. Jurnal Ilmu Keluarga dan Konsumen.1(1): 1-15.

Soares, FV., \& Silva, E. (2010). Conditional Cash Transfer Programmes And Gender Vulnerabilities: Case Studies of Brazil, Chile and Colombia. 
Working Paper number 69, September 2010, International Policy Centre for Inclusive Growth.

Stampini, M., \& Tornarolli, L. (2012). The Growth of Conditional Cash Transfers in Latin America and the Caribbean: Did They Go Too Far?. Policy Paper IZA, 49, 1-30.

Suntiana, L., Kanto, S., \& Soenyono. (2015). Rancangan Model Kebijakan Penanggulangan Kemiskinan Dalam Perspektif Pemberdayaan Perempuan (Kajian Terhadap Implementasi Program Keluarga Harapan di Kecamatan Sumberbaru Kabupaten Jember). Wacana, 18(3), 146-157.

[TNP2K] Tim Nasional Percepatan Penanggulangan Kemiskinan. Program Keluarga Harapan: Upaya Memutus Rantai Kemiskinan. (tersedia pada) http://www.tnp2k.go.id/images/uploads/downloads/Fact-sheet-PKH2015_Juni-1.pdf

Utomo, D., Hakim, A., \& Ribawanto, H. (2014). Pelaksanaan Program Keluarga Harapan Dalam Meningkatkan Kualitas Hidup Rumah Tangga Miskin : Studi Pada Unit Pelaksana Program Keluarga Harapan Kecamatan Purwoasri Kabupaten Kediri. Jurnal Administrasi Publik, 2(1), 29-34. 